\title{
KONCEPCJA EDYTORSTWA JAKO SUBDYSCYPLINY BIBLIOLOGICZNEJ W PRACACH LEONA MARSZAŁKA (1912-1996)
}

Edytorstwo bibliologiczne - rozwój, stan obecny. Leon Marszałek — wybitny polski wydawca-praktyk, teoretyk edytorstwa, działacz. Model edytorstwa jako dyscypliny bibliologicznej zawarty w pracach Leona Marszałka.

SŁOWA KLUCZOWE: Leon Marszałek (1912-1996), edytorstwo, zagadnienia wydawnicze, bibliologia

\section{CEL PRACY I USTALENIA TEORETYCZNE — EDYTORSTWO BIBLIOLOGICZNE}

Przegląd kierunków studiów (zarówno licencjackich i magisterskich, jak i podyplomowych) oraz specjalności i modułów kształcenia oferowanych obecnie przez polskie uczelnie pozwala zauważyć, że edytorstwo na dobre zadomowiło się w kształceniu uniwersyteckim, przede wszystkim polonistycznym i bibliotekoznawczym. Termin ten pojawia się też w nazwach jednostek akademickich zakładów, katedr, co odzwierciedla obecność tematyki wydawniczej w prowadzonych przez nie badaniach naukowych. Ta swego rodzaju popularność edytorstwa niezaprzeczalnie jest związana z niezwykle intensywnym rozwojem współczesnego rynku wydawniczego, przemianami roli publikowania w komunikacji społecznej i przyrostem towarzyszącej temu refleksji teoretycznej. $Z$ tego względu wspomniana popularność dotyczy przede wszystkim zagadnień edytorstwa bibliologicznego - młodszego brata dojrzałego już edytorstwa naukowego (obejmującego edy torstwo dzieł literackich i edytorstwo źródeł historycznych), którego rozwój współcześnie nie wydaje się aż tak intensywny¹.

1 W odniesieniu do edytorstwa naukowego pojawiają się wręcz głosy mówiące o jego kryzysie — por. na przykład M. Kawka, Tekstologia, teoria tekstu, edytorstwo..., „Konspekt” 2004, nr 19, s. 42-43; M. Strzyżewski, Współczesne edytorstwo to złożona całość, „Wielogłos. Pismo Wydziału Polonistyki UJ" 2012, nr 3, s. 165-172. 
Termin „edytorstwo” jest pojęciem bardzo kłopotliwym w języku polskim ze względu na jego wieloznaczność i szeroki zakres. Z jednej strony odnosi się ono do praktycznej działalności, z drugiej zaś do leżącej u jego podstaw teorii, przy czym w obu wypadkach obejmuje swym zakresem trzy bardzo ściśle z sobą powiązane i wymagające integracji ${ }^{2}$, ale jednak odrębne obszary identyfikowane przez towarzyszące mu w przytoczonych już nazwach określenia.

Edytorstwo filologiczne (edytorstwo dzieł literackich, tekstologia) ma długą tradycję i przez długi czas omawiany termin stosowany był w odniesieniu właśnie do niego. Związane jest z krytyką tekstu — najczęściej dawnego tekstu literackiego - i przygotowaniem go do publikacji w postaci tak zwanego wydania krytycznego. W wymiarze praktycznym ma charakter działalności naukowej, a jako teoria - status specjalności filologicznej ${ }^{4}$, na którą składa się „zespół naukowo uzasadnionych metod ustalania i udostępniania poprawnego tekstu utworów literatury jako sztuki posługującej się językiem dla celów wyrazu artystycznego" ". Edytorstwo źródeł historycznych ma zbliżony charakter, przystosowuje jednak do opublikowania i naukowego wykorzystania teksty źródłowe, najczęściej dokumentujące przeszłość, a więc o charakterze historycznym. Tym samym włączane jest do kręgu nauk pomocniczych historii ${ }^{6}$. Trzeci obszar to wreszcie zespół działań, które „pozwalają tekst opracowany przez autora czy zespół ludzi, wraz z wszystkimi do niego załącznikami, jak na przykład ilustracje, tabele, mapy, przeobrazić w publikację"7, umożliwiając tym samym jego rozpowszechnienie - przede wszystkim poprzez wprowadzenie na rynek wydawniczo-księgarski. Teoretyczną podstawę tej działalności stanowi wspomniane już edytorstwo bibliologiczne (nazywane też czasami edytorstwem praktycznym), będące głównym przedmiotem niniejszych rozważań. W najogólniejszym ujęciu

2 Jan Trzynadlowski w artykule Edytorstwo i zagadnienia wydawnicze. Stan i perspektywy badawcze omawiał jako składające się na wspólny dorobek prace z zakresu edytorstwa naukowego i wydawniczego, pisał w odniesieniu do tych ostatnich o „sprawach edytorsko-wydawniczych”, czyli zagadnieniach ,związków zachodzących między działaniami tekstowymi a warsztatowo-wydawniczymi" (J. Trzynadlowski, Edytorstwo i zagadnienia wydawnicze. Stan i perspektywy badawcze, „Studia o Książce” 12, 1982, s. 63). Wzajemnym powiązaniom między edytorstwem filologicznym a wydawniczym poświęcona jest w dużej mierze praca tego samego autora pt. Autor, dzieło, wydawca (Wrocław 1988). Por. też M. Strzyżewski, op. cit.; M. Kawka, Trzy edytorstwa czy jedno? O potrzebie ksztatcenia wydawców ksiązek w Akademii Pedagogicznej, „Konspekt” 2001, nr 6, s. 65-68; J.S. Gruchała, Uwagi o akademickim ksztatceniu edytorów, „Konspekt” 2004, nr 19 , s. $39-41$.

3 Jego początki w Polsce związane są z rokiem 1884 i Zjazdem im. Jana Kochanowskiego w Krakowie.

${ }^{4}$ Zob. J.S. Gruchała, Tekstologia (edytorstwo naukowe), [hasło w:] Encyklopedia książki, pod red. A. Żbikowskiej-Migoń, M. Skalskiej-Zlat, t. 1, Wrocław 2017, s. 583.

5 K. Górski, Sztuka edytorska. Zarys teorii, Warszawa 1956, s. 11.

6 Zob. J. Szymański, Nauki pomocnicze historii, Warszawa 1983, s. 711 n.

7 J. Dunin, Wstęp do edytorstwa, Łódź 2005, s. 9. 
edytorstwo bibliologiczne obejmuje „całość zagadnień związanych z wytwarzaniem książki, rozumianej jako połączenie treści tekstu (utworu piśmienniczego) i jego materialnej formy (utrwalonej na różnych nośnikach) przystosowanej do publicznego rozpowszechnienia" 8 . Przedmiotem jego zainteresowania jest więc „proces wydawniczy i jego poszczególne etapy (od inicjatywy wydawniczej, poprzez opracowanie merytoryczne treści, po publikację) wraz z ich otoczeniem społecznym, kulturowym, ekonomicznym i technologicznym"9.

Tak rozumiane edytorstwo bibliologiczne zrodziło się z praktyki wydawniczej i rozwijało równolegle $\mathrm{z}$ nią niemal od początku istnienia książki, a od wynalezienia druku głównie w kręgu prac z teorii i - przede wszystkim — historii drukarstwa. Kształtująca się nauka o książce w naturalny sposób doceniła ten dorobek. Od początku w teoretycznych koncepcjach bibliologii uwzględniano zagadnienia wydawnicze, choć ujmowane głównie w perspektywie historycznej. Kolejni teoretycy odmiennie określali ich zakres i usytuowanie w obrębie dyscypliny, jednak niemal zawsze włączali je do swoich modeli tej nauki ${ }^{10}$. Niestety mimo to do drugiej połowy XX wieku zagadnienia wytwarzania książki nie stały się obszarem badanym systematycznie i programowo. Nie funkcjonowały też pod nazwą ,edytorstwo”. W Polsce w tym znaczeniu, jako nazwy części obszaru bibliologii, użył tego terminu dopiero w 1951 roku Adam Łysakowski w pracy Przedmiot i zadania bibliografii, pisząc: „Do ogólniejszego zakresu [nauki o książce - B.H.] oprócz bibliografii należy bibliotekarstwo i bibliotekoznawstwo, bibliologia systematyczna, zagadnienia pisarstwa i edytorstwa, teoria czytelnictwa, metodyka pracy umysłowej z książką"11.

Intensywny rozwój edytorstwa jako odrębnego pola badawczego nauki o książce nastąpił dopiero $\mathrm{w}$ drugiej połowie $\mathrm{XX}$ wieku, gdy ogromny przyrost produkcji wydawniczej zrodził wyraźną potrzebę teorii i tym samym stał się bodźcem do podejmowania naukowych rozważań nad działalnością wydawniczą — już nie tylko w ujęciu historycznym, lecz także w kontekście współczesności. Liczne inicjatywy wydawnicze podejmowane w Polsce po 1945 roku wymagały sformułowania zasad zarówno opracowania tekstologicznego, jak i ukształtowania wydawniczego publikowanych tekstów ${ }^{12}$. Nie bez znaczenia dla rozwoju tej dziedziny wiedzy była potrzeba kształcenia, związana z postępującą profesjonalizacją zawodów ludzi książki ${ }^{13}$.

8 B. Hojka, Edytorstwo, [hasło w:] Encyklopedia książki, t. 1, s. 601.

9 Ibidem, s. 600.

10 Więcej na ten temat zob. na przykład K. Migoń, Nauka o książce. Zarys problematyki, Wrocław 1984; L. Marszałek, Edytorstwo publikacji naukowych, Warszawa 1986, rozdz. 1. Edytorstwo w nauce o książce, s. 17-40.

11 A. Łysakowski, Przedmiot i zadania bibliografii, [w:] Wykłady z dokumentacji naukowo-technicznej, pod red. T. Zamoyskiego, Warszawa 1951, s. 69.

12 J. Trzynadlowski, Edytorstwo i zagadnienia wydawnicze..., s. 62.

13 Por. B. Hojka, op. cit. 
W naszym kraju próby zdiagnozowania stanu badań edytorskich i wyraźne postulaty ich dalszego rozwoju pojawiły się w latach 70. i 80. XX wieku. W 1975 roku Grażyna Talar, podsumowując przegląd piśmiennictwa bibliologicznego pod kątem obecności w nim zagadnień wydawniczych, pisała: „Materiał zawarty w publikacjach, które zostały przedstawione w niniejszym przeglądzie, dowodzi istnienia w ramach nauki o książce bogatej problematyki edytorstwa [...]"14. Według autorki składały się na nią przede wszystkim cztery grupy problemów: edytorstwo jako subdyscyplina bibliologii, edytorskie aspekty historii książek, etapy procesu wydawniczego i sztuka książki ${ }^{15}$. Formułując postulaty odnośnie do dalszego rozwoju badań edytorskich, Talar wskazywała jednak cały szereg zagadnień, które również powinny znaleźć się w kręgu zainteresowania bibliologów. Były to: historia organizacji edytorstwa, ewolucja form pracy w wydawnictwach, dzieje redakcyjnego kształtowania tekstu, specyficzne cechy opracowania edytorskiego różnych rodzajów piśmiennictwa i różnych typów edycji, wreszcie działalność i metody pracy współczesnych wydawnictw ${ }^{16}$.

Potrzebę dalszego rozwoju badań edytorskich dostrzegał również Leon Marszałek, który zauważał jednocześnie brak ich spójnego i kompletnego charakteru. Niniejszy artykuł jest próbą odtworzenia koncepcji edytorstwa zawartej w pracach tego wybitnego wydawcy, praktyka i teoretyka działalności wydawniczej, który konsekwentnie propagował ideę edytorstwa jako odrębnej dyscypliny uprawianej w ramach nauki o książce, postulował prowadzenie systematycznych badań w tym zakresie i podejmował próby sformułowania ich programu.

\section{LEON MARSZAŁEK (1912-1996) — WYDAWCA, TEORETYK I PROPAGATOR EDYTORSTWA}

Leon Marszałek urodził się w Poznaniu, tam też skończył studia na Wydziale Prawno-Ekonomicznym Uniwersytetu Poznańskiego. Jego życie zawodowe rozpoczęło się pracą w administracji państwowej, po wojnie zaś (w czasie której prowadził działalność konspiracyjną jako członek Związku Harcerstwa Polskiego, współtwórca i ostatni naczelnik Szarych Szeregów) było związane z polskim ruchem spółdzielczym ${ }^{17}$.

14 G. Talar, Edytorstwo a nauka o książce, „Studia o Książce” 5, 1975, s. 176.

15 Ibidem, s. 162.

16 Ibidem, s. 176.

17 W dalszej części tekstu omówiono wyłącznie dorobek Leona Marszałka związany z edytorstwem i praktyką wydawniczą. Więcej na temat bogatej biografii i innych obszarów jego zainteresowań zob. M. Kocięcka, Leon Marszatek, „Przegląd Biblioteczny” 1996, nr 4, s. 385-388; eadem, Wspomnienie o Dyrektorze Leonie Marszałku, „Biuletyn Informacyjny Biblioteki Narodowej" 1966, s. 50-51. 
Ze światem książek Leon Marszałek związał się zawodowo w 1951 roku, kiedy to rozpoczął pracę w Państwowym Wydawnictwie Naukowym. Od 1956 roku był redaktorem naczelnym wydawnictw encyklopedycznych i słownikowych PWN - kierował między innymi pracami nad Mała Encyklopedia Powszechna (1956) i Wielka Encyklopedia Powszechna PWN (t. 1-12, 1962-1969), tworząc edytorski warsztat wydawnictw informacyjnych ${ }^{18}$.

W latach 1969-1972 Marszałek pracował w Departamencie Wydawnictw Ministerstwa Kultury i Sztuki, był też zastępcą dyrektora w Naczelnym Zarządzie Wydawnictw. Od roku 1972 pełnił funkcję wicedyrektora Biblioteki Narodowej, wprowadzając wiele zmian i usprawnień zarówno w działalności bibliotecznej, jak i naukowej tej instytucji. W 1978 roku przeszedł na emeryturę, która okazała się okresem wytężonej pracy twórczej, owocującej licznymi publikacjami ${ }^{19}$.

Bardzo ważnym obszarem w życiu Leona Marszałka była związana z edytorstwem działalność dydaktyczna i społeczna. Przez lata prowadził wykłady z zakresu edytorstwa na Wydziale Dziennikarstwa, w Instytucie Bibliotekoznawstwa i Informacji Naukowej oraz w Studium Edytorstwa przy Wydziale Filologii Polskiej Uniwersytetu Warszawskiego. W latach 1957-1970 był prezesem zarządu Polskiego Towarzystwa Wydawców Książek, a w latach 1988-1990 redaktorem czasopisma „Editor” wydawanego przez to stowarzyszenie ${ }^{20}$.

Jego dorobek edytorski obejmuje wreszcie prace teoretyczne dotyczące zagadnień wydawniczych. Najważniejsza z nich to niezaprzeczalnie doceniane i do dziś wykorzystywane w kształceniu wydawców Edytorstwo publikacji naukowych (pierwsze wydanie z podtytułem Zarys problematyki - Warszawa 1974, wydanie rozszerzone - Warszawa 1986) ${ }^{21}$. Warto jednak wymienić także opracowaną pod kierunkiem Marszałka instruktażową publikację Zasady typowego opracowania edytorskiego z 1962 roku (Warszawa) oraz wydany przez Centrum Ustawicznego Kształcenia Bibliotekarzy w Warszawie w 1988 roku podręcznik Podstawowe wiadomości z edytorstwa i ksiegarstwa, wreszcie artykuły publikowane w czasopismach naukowych ${ }^{22}$ i branżowych ${ }^{23}$.

18 Jego założenia przedstawił w artykule pt. Warsztat edytorski Wielkiej Encyklopedii Powszechnej, opublikowanym w „Roczniku Biblioteki Narodowej” w 1966 roku.

19 M. Kocięcka, Leon Marszałek..., s. 388.

20 M. Kocięcka, Marszałek Leon, [hasło w:] Słownik Pracowników Książki Polskiej, Suplement II, Warszawa 2000, s. 104-105.

${ }^{21}$ Zob. J.W. Zawisza, [rec.] L. Marszałek, Edytorstwo publikacji naukowych. Zarys problematyki, „Roczniki Biblioteczne” 20, 1976, s. 437-439.

22 L. Marszałek, Warsztat edytorski...; idem, Polskie encyklopedie i słowniki bibliologiczne, „Przegląd Biblioteczny” 1985, z. 3/4, s. 401-423; idem, Publikacje naukowe, „Zagadnienia Naukoznawstwa" 1984, z. 1, s. 55-91 (opublikowany przed wydaniem książki rozdział Edytorstwa publikacji naukowych).

23 L. Marszałek, „Editor” - forum wydawców, „Editor” 1, 1988, s. 7-26; idem, Edytorstwo — dyscyplina nauki o książce, „Przegląd Księgarski i Wydawniczy” 1970, nr 23/24, s. 2, 4-5; 
W swoich pracach poza uporządkowaniem konkretnych zagadnień związanych z praktyką wydawniczą przedstawiał własny model edytorstwa jako odrębnej dyscypliny, konsekwentnie uzasadniając konieczność jego wdrożenia i rozwijania. Najbardziej obszernie i całościowo przedstawił założenia postulowanej dyscypliny w tekście zatytułowanym Zagadnienia wydawnicze w nauce o książce, który ukazał się w 1976 roku w tomie Metodologia bibliotekoznawstwa i nauki o informacji naukowej. Materiały z sesji naukowej zorganizowanej przez Instytut Bibliotekoznawstwa i Informacji Naukowej oraz Bibliotekę Gtówną UAM (17-18 XII 1974 R. $)^{24}$.

\section{MODEL TEORETYCZNY I PROGRAM BADAŃ EDYTORSKICH LEONA MARSZAŁKA}

W opublikowanym w 1970 roku artykule zatytułowanym Edytorstwo - $d y$ scyplina nauki o książe Leon Marszałek określił edytorstwo jako ,jeszcze słabo wykształconą dyscyplinę szczegółową w obrębie nauki o książce" 25 i z rozczarowaniem stwierdził, iż mimo szerokiego zakresu księgoznawstwa (przywoływał tu koncepcję Karola Głombiowskiego) problematyka wydawania i rozpowszechniania książek stosunkowo rzadko staje się przedmiotem zainteresowania badaczy ${ }^{26}$. Dlatego też pisał dalej wprost o potrzebie kreowania odrębnej dyscypliny wypełniającej tę lukę. Artykuł opublikowany w „Przeglądzie Księgarskim i Wydawniczym" nie ma charakteru naukowego wykładu, miał raczej przedstawić bardzo skrótowo koncepcję takiej dyscypliny szerszemu gronu czytelników i zainicjować dyskusję na ten temat. Sam autor zachęcał w nim zresztą do polemiki i formułowania uwag, również krytycznych.

Przedmiotem edytorstwa według Marszałka miałoby być wydawanie książek wszystkich rodzajów, a dokładniej ,programowanie wydawnicze [...], czynności redakcyjne zmierzające do przygotowania maszynopisu do druku i opracowania szaty edytorskiej oraz czynności w fazie produkcji drukarskiej [...], wreszcie rozpowszechnianie książek, czyli organizowanie dotarcia książki do odbiorcy" 27 . Autor wskazał tym samym trzy główne obszary badawcze edytorstwa: zagadnienia programowania, wytwarzania i rozpowszechniania publikacji. Zaznaczył

idem, Pierwsze encyklopedie uniwersalne Państwowego Wydawnictwa Naukowego, „Editor” 3, 1990, s. 73-92; idem, Wydawcy wobec wyzwania czasu, „Editor” 2, 1989, s. 11, 14.

24 L. Marszałek, Zagadnienia wydawnicze w nauce o ksiażce, [w:] Metodologia bibliotekoznawstwa i nauki o informacji naukowej. Materiaty z sesji naukowej zorganizowanej przez Instytut Bibliotekoznawstwa i Informacji Naukowej oraz Bibliotekę Gtówna UAM (17-18 XII 1974 R.), Poznań 1976, s. 47-63.

25 Idem, Edytorstwo - dyscyplina nauki o książce, s. 2.

26 Jako możliwą przyczynę takiego stanu rzeczy Marszałek wskazuje to, że bibliologia jako nauka w największej mierze uprawiana jest przez bibliotekoznawców (ibidem).

27 Ibidem, s. 4. 
przy tym, że w każdym z tych zakresów należy uwzględniać specyficzne procesy związane z funkcjonowaniem różnych typów publikacji, które powinny stać się przedmiotem odrębnych badań.

W tym krótkim, popularyzującym ideę rozwoju badań edytorskich tekście Marszałek odniósł się też do statusu edytorstwa jako nauki, stwierdzając, że nie jest ono ani nauką czysto teoretyczną, ani czysto praktyczną:

Zawiera [...] elementy opisowe, klasyfikacyjne, próbuje znaleźć prawidłowości, opisuje rzeczywistość taką, jaką ona jest. Ale jednocześnie, dzięki pogłębionemu opisowi procesów dotyczących wydawania książek $i$ ich rozpowszechniania, może też określić reguły postępowania zmierzające do osiągnięcia wysokiej skuteczności w programowaniu, wytwarzaniu i rozpowszechnianiu, czyli opisuje postulowaną rzeczywistość ${ }^{28}$.

Ten teoretyczno-praktyczny charakter jest zresztą według Marszałka cechą całej nauki o książce; w przypadku praktyki edytorskiej, polegającej na projektowaniu wydawniczej formy książki, ma jednak szczególne znaczenie.

Tekst kończył postulat przygotowania programu badań i szybkiej jego realizacji. Pierwsze zadanie zrealizował sam Marszałek w kolejnym artykule poświęconym edytorstwu jako szczegółowej dyscyplinie bibliologii. Praca Zagadnienia wydawnicze w nauce o książce, opublikowana w 1976 roku w tomie pokonferencyjnym Metodologia bibliotekoznawstwa i nauki o informacji naukowej (Poznań), zawiera pełniejszą prezentację jego koncepcji edytorstwa i programu badań edytorskich, jest jednocześnie próbą zainicjowania procesu jego wdrażania, a więc po prostu prowadzenia w sposób spójny i systematyczny badań edytorskich.

W obszernym wprowadzeniu autor omówił zakres pojęcia ,zagadnienia wydawnicze", sygnalizując między innymi problem uwzględniania w obrębie nauki o książce zagadnień techniki wydawniczej, ekonomiki książki i jej estetyki, do którego zresztą odniesie się we własnej koncepcji. Poruszył także kwestię obiektu działań edytorskich, za który uznawane bywają albo sama książka, albo książka i czasopismo.

W dalszej części tekstu Marszałek zaprezentował kolejne modele teoretyczne bibliologii, wskazując na sposób rozumienia i usytuowania w nich problematyki wydawniczej. Odwołał się między innymi do koncepcji Gabriela Peignota i Paula Otleta, rosyjskich badaczy Nikołaja Lisowskiego i Aleksandra Łowiagina, wreszcie do teorii przedstawicieli polskiej bibliologii: Joachima Lelewela, Karola Estreichera, Stefana Vrtela-Wierczyńskiego, Jana Muszkowskiego, Karola Głombiowskiego. Przegląd ten jest podstawą formułowanego później argumentu o długiej tradycji obecności zagadnień edytorskich w nauce o książce. Wśród omawianych koncepcji eksponujących miejsce zagadnień wydawniczych w bibliologii na szczególną uwagę zasługiwała według Marszałka propozycja Ibrama I. Barsuka, który wśród szczegółowych dyscyplin tworzących strukturę nauki o książce wymienił na pierwszym miejscu właśnie edytorstwo rozumiane jako badania działalności

28 Ibidem. 
wydawniczej, a zaraz za nim sztukę książkową, której przedmiotem jest artystyczne i poligraficzne ukształtowanie książki ${ }^{29}$.

Autor omówił wreszcie przemiany, jakie zaszły na rynku wydawniczym po drugiej wojnie światowej, składające się na zjawisko „narodzin wielkiego przemysłu wydawniczego" 30 . Przemiany te i wynikające z nich potrzeby sprawiły, że „koncepcja odrębnej dyscypliny w obrębie nauki o książce zajmującej się zagadnieniami wydawniczymi stała się niemal koniecznością" ${ }^{31}$. Dyscyplina ta powinna należeć do bibliologii rozumianej jako nauka kompleksowa, a jej nazwą według Marszałka powinno być — ze względu na rozpowszechniającą się praktykę językową - edytorstwo.

Ze względu na cel niniejszego tekstu najważniejszymi fragmentami pracy Marszałka są te dotyczące zakresu i przedmiotu badań edytorstwa. Aby je określić, autor odpowiadał na pytanie: ,jakie produkty działalności wydawniczej i jakie procesy (funkcje) wydawnicze uczynimy przedmiotem badań" 32 .

Ze względu na poszerzające się stale pole działań edytorskich i nowe formy publikacji Marszałek uznał, że przedmiotem zainteresowania edytorstwa powinny się stać wszystkie produkty działalności wydawniczej. To sformułowanie zakładało, że przedmiotem tym są nie tylko książki i dodatkowo dawało możliwość jego ciągłego poszerzania o pojawiające się z czasem nowe formy publikacji. W rzeczywistości lat 70. XX wieku poza książkami były to: nuty, mapy, czasopisma (specjalistyczne, przede wszystkim naukowe i fachowe), niektóre dokumenty życia społecznego i dokumenty audiowizualne (zwłaszcza stanowiące uzupełnienie



Procesy, którymi powinno interesować się edytorstwo, według Marszałka wynikały z istoty samej książki, która jest jednocześnie formą przekazu treści, dziełem sztuki graficznej, wytworem przemysłu poligraficznego i towarem na rynku księgarskim ${ }^{34}$. Każdy z tych wymiarów książki jest bowiem efektem określonych działań wydawniczych, z którymi wiążą się różne problemy badawcze. Pierwszym z nich, i najważniejszym, jest dokonywanie wyboru i wszystko, co się z tym wiąże. Dla tego obszaru autor zaproponował nazwę ,programowanie wydawnicze”. Rozumiał je jako „określenie celów działalności, opis potrzeb oraz ustalenie sposobów realizacji tych celów i zaspokojenia potrzeb" ${ }^{35}$. Program wydawniczy (ten termin uznany jest przez autora za właściwszy niż ,repertuar

29 L. Marszałek, Zagadnienia wydawnicze w nauce o książce, s. 54-55.

30 Ibidem, s. 54.

31 Ibidem. Zważywszy na czas wydania tekstu i ówczesną sytuację polityczną, nie dziwi, że konstatacji tej towarzyszyła teza o szczególnej intensywności zarówno tych potrzeb, jak i możliwości ich zaspokojenia w krajach socjalistycznych.

32 Ibidem, s. 57.

33 Ibidem.

34 Ibidem, s. 58.

35 Ibidem, s. 59. 
wydawniczy") powinien być wedle Marszałka podstawową kategorią edytorstwa i jedną z kluczowych kategorii całej nauki o książce. Programowanie wydawnicze jest próbą racjonalizacji działań wydawców, ,pozwala na eliminowanie decyzji przypadkowych, czyli nieistotnych, a zwiększanie wyborów istotnych, racjonalnie uzasadnionych, wynikających z badań, ekspertyz, ze sprawnie działającego systemu informacji”, ${ }^{\text {". }}$.

Oczywiście takie rozumienie programowania może budzić wątpliwości, które - choć częściowo - formułował sam Marszałek. Zaznaczał bowiem, że działalność wydawnicza jest tak różnorodna, piśmiennictwo tak bogate, a motywacje czytelnicze tak złożone, iż nie da się tego obszaru działalności w pełni usystematyzować i podporządkować zasadom racjonalności. Dziś, w dobie nadmiaru informacji i rozpowszechnianych treści, te wątpliwości są jeszcze większe, a rola społeczna i cele, jakim powinna służyć działalność współczesnego wydawcy, zmieniają się diametralnie. Tym bardziej więc obecnie kwestia wyborów, choć w innym kontekście i z uwzględnieniem odmiennej sytuacji, wydaje się w działalności wydawniczej kluczowa, a jej włączenie w zakres badań nad edytorstwem nieodzowne.

Druga po programowaniu wydawniczym grupa zagadnień stanowiących przedmiot edytorstwa jako dyscypliny naukowej wiąże się w koncepcji Marszałka z procesami wytwarzania książki, czy — jak powiedzielibyśmy dziś — publikacji. $\mathrm{W}$ ich zakres wchodzi przygotowanie redakcyjne maszynopisu pod względem treści, opracowanie kompozycji artystyczno-graficznej, sam proces wykonania technicznego oraz modele organizacyjne tych działań i ich aspekty ekonomiczne ${ }^{37}$. Kolejne obszary zainteresowania edytorstwa to zagadnienia redakcyjne (rozpatrywane w kontekście zróżnicowania typów publikacji) z metodami opracowania redakcyjnego samego tekstu autorskiego.

Dyskusyjne jest w opinii Marszałka włączenie estetyki książki i jej ekonomiki do zagadnień badanych przez edytorstwo. Pierwszą uznawał za pole badań interdyscyplinarnych, które powinny być jednak inicjowane przez edytorów lub grafików-artystów i z tego względu powinny znaleźć swoje miejsce w programie badań edytorskich. Poza edytorstwem pozostawiał natomiast zagadnienia samej techniki poligraficznej ze względu na jej ustabilizowany status w obszarze nauk technicznych ${ }^{38}$.

Nieco więcej trudności sprawiają według autora zagadnienia ekonomiki książki, które raczej nie są obiektem zainteresowania nauk ekonomicznych. Wynika to przede wszystkim ze specyfiki działalności wydawniczej, która z jednej strony niezaprzeczalnie jest nastawiona na generowanie przychodów, z drugiej zaś w dużej mierze ma charakter działalności kulturalnej, której komercyjny charak-

\footnotetext{
36 Ibidem, s. 60.

37 Ibidem.

38 Ibidem, s. 61.
} 
ter często nie jest najważniejszy. Jednak ostatecznie, powołując się na przyjęcie takiego rozwiązania w innych krajach i na istniejącą wyraźną potrzebę, opowiadał się Marszałek za włączeniem do edytorstwa także zagadnień ekonomicznych.

Trzecia, ostatnia grupa zagadnień stanowiących przedmiot zainteresowania edytorstwa w koncepcji Leona Marszałka to problematyka rozpowszechniania produktów działalności wydawniczej. Jak pisał, samo księgarstwo pozostaje poza obszarem edytorstwa, jednak wiele zagadnień sytuuje się na styku tych dyscyplin, co pozwala przypuszczać, że będą stawiać pytania wymagające prowadzenia wspólnych badań. To samo dotyczy zresztą badań czytelnictwa i problemów bibliografii ${ }^{39}$.

We wszystkich tych obszarach edytorstwo interesować powinien zarówno stan obecny, jak i przeszłość. Nie negując bowiem odrębności historii książki, Marszałek uważał, że „ze względu na specjalny punkt zainteresowań należy uwzględnić w ramach edytorstwa badania historyczne dotyczące rozwoju ruchu wydawniczego, jego wielkich warsztatów edytorskich" ${ }^{\text {"40 }}$.

Poszerzoną nieco wersję zaprezentowanego modelu teoretycznego przedstawił Marszałek dziesięć lat później w pierwszym rozdziale wspominanej już pracy pt. Edytorstwo publikacji naukowych. Rozdział zatytułowany Edytorstwo $w$ nauce o książce w dużej mierze jest przytoczeniem wcześniejszych propozycji opatrzonych jednak nieco szerszym komentarzem. $Z$ tego względu praca ta będzie omówiona tylko w tych fragmentach, które prezentują uzupełnione lub zmienione poglądy autora. Marszałek konsekwentnie posługiwał się tu już terminem „edytorstwo" w odniesieniu do dyscypliny bibliologicznej, pisał też o większej jasności co do jej pola badawczego i głównych kierunków zainteresowań badaw$\mathrm{czych}^{41}$. Postulował w związku z tym już nie samo kreowanie dyscypliny, lecz przykładanie większej wagi do prowadzonych w jej obrębie badań i stwarzanie sprzyjających ich rozwojowi warunków (między innymi poprzez powoływanie zespołów badawczych, intensyfikację działalności szkół wyższych w tym zakresie czy wreszcie stworzenie specjalistycznego czasopisma) ${ }^{42}$.

Formułując cel badań edytorskich, odwoływał się wyraźnie do funkcjonalnej orientacji w nauce o książce, pisząc: ,zadaniem edytorstwa jest uporządkowany opis działalności wydawniczej (systematyzacja i typologia), badanie prawidłowości tej działalności z punktu widzenia funkcji książki w społeczeństwie"43. Określając zaś metodologiczne zaplecze edytorstwa, wyraźnie wskazał właśnie na metodę funkcjonalną jako mającą najszersze zastosowanie, obok oczywiście

\footnotetext{
39 Ibidem, s. 61-62.

40 Ibidem, s. 62.

41 L. Marszałek, Edytorstwo publikacji naukowych, s. 37.

42 Ibidem, s. 37-38.

43 Ibidem, s. 31.
} 
innych metod, takich jak historyczna, filologiczna, logiki formalnej, bibliograficzna, statystyczna, analityczno-teoretyczna czy też metoda analizy systemowej ${ }^{44}$.

Omawiając procesy będące przedmiotem edytorstwa, nieco szerzej niż dziesięć lat wcześniej ujął problematykę wytwarzania: w pierwszej kolejności wymienia ,zagadnienia organizacyjne całego ruchu wydawniczego oraz samych wydawnictw"45, a w ich obrębie między innymi kwestie tworzenia i funkcjonowania wyspecjalizowanych warsztatów edytorskich (na przykład wydawnictw podręcznikowych, encyklopedycznych, słownikowych). Wydaje się to jak najbardziej uzasadnionym uzupełnieniem, a rozwój edytorstwa współczesnego pokazuje, że rzeczywiście dzieje i modele funkcjonowania poszczególnych typów i rodzajów publikacji są stałym obiektem naukowej refleksji.

Zmianie uległo stanowisko Marszałka w stosunku do zagadnień ekonomiki książki. W artykule z roku 1976 uznał bowiem, że ,Jakkolwiek [...] włączenie ekonomicznych zagadnień do edytorstwa wpływa na mniej jednolity charakter tej dyscypliny, to jednak potrzeby praktyki grają tu rolę rozstrzygającą"46. W omawianym tekście (z 1986 roku) ostateczne rozstrzygnięcie jest odmienne, a decydujący okazuje się humanistyczny wymiar nauki, jaką jest bibliologia: „Charakter nauki o książce jako kompleksowej nauki grupującej dyscypliny humanistyczne skłania do wyłączenia spraw ekonomicznych z zakresu badań edytorstwa. Uznając jednak interdyscyplinarny charakter badań nad zagadnieniami ekonomicznymi wydawnictwa, można by przypisać edytorstwu rolę inicjującą w tym zakresie"47.

Ten sam argument o humanistycznym charakterze nauki o książce jako uzasadniającym wyłączenie z zakresu edytorstwa techniki poligraficznej i ekonomiki książki podał zresztą również we wstępie do wydanych w 1988 roku Podstawowych wiadomości z edytorstwa i ksiegarstwa ${ }^{48}$. Był to podręcznik przeznaczony dla bibliotekarzy, z założenia zawierający wiadomości najbardziej podstawowe, a zatem pozbawiony szerszych rozważań teoretycznych na temat naukowego statusu edytorstwa. Pewne uporządkowania pojawiają się jednak w przywołanym już wstępie. Omawiając wieloznaczność terminu „edytorstwo”, Marszałek pisał w nim: „W ostatnich dwudziestu latach zaczyna się upowszechniać rozumienie edytorstwa jako szczegółowej dyscypliny w obrębie nauki o książce (bibliologii). Edytorstwo zajmuje się zagadnieniami programowania, wytwarzania i rozpo-

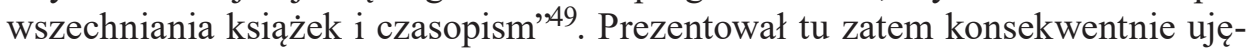
cie edytorstwa jako dyscypliny księgoznawczej, skupiającej się na wymienionych trzech podstawowych obszarach.
44 Ibidem, s. 37.
45 Ibidem, s. 31.
46 L. Marszałek, Zagadnienia wydawnicze w nauce o książce, s. 61.
47 Idem, Edytorstwo publikacji naukowych, s. 36.
48 Idem, Podstawowe wiadomości z edytorstwa i księgarstwa, Warszawa 1988, s. 6.
49 Ibidem, s. 5. 


\section{PODSUMOWANIE - POGLĄDY LEONA MARSZAŁKA A EDYTORSTWO WSPÓŁCZESNE}

Koncepcja edytorstwa Leona Marszałka nie stała się wprawdzie przedmiotem bezpośrednich omówień czy polemik, jednak nawiązania do jego prac obecne w publikacjach bibliologicznych świadczą o znaczeniu jego dorobku dla rozwoju tej dyscypliny. Karol Głombiowski, w kluczowej dla polskiej szkoły bibliologicznej rozprawie Ksiązka w procesie komunikacji społecznej, objaśniał udział wydawcy w tworzeniu komunikatywności książki, powołując się między innymi na Edytorstwo prac naukowych, którego autora określił mianem „wybitnego znawcy przedmiotu" ${ }^{50}$. Do tej samej pracy odsyłał czytelnika Krzysztof Migoń, omawiając w monografii Nauka o ksiażce. Zarys problematyki edytorstwo jako dyscyplinę bibliologiczną budującą od niedawna swoją teorię ${ }^{51}$. Odwołań do poglądów Marszałka nie brak też i we współczesnych opracowaniach z zakresu edytorstwa, zarówno tych dotyczących jego teorii, jak i problemów szczegółowych ${ }^{52}$.

W dobie interdyscyplinarności i badań łączących różnorodność perspektyw i stosowanych metodologii pytanie o autonomiczność dyscyplin naukowych wydaje się mniej istotne niż kiedyś. Nie znaczy to jednak, że nie warto go stawiać. Edytorstwo bibliologiczne jako obszar działalności naukowej ma w Polsce do dziś nieustabilizowany status. Niewątpliwie jest to kompleks zagadnień mieszczący się w obrębie nauki o książce, który ma jednak — ze względu na swój obiekt i wykorzystywane metody - interdyscyplinarny charakter. Nie ulega też wątpliwości, że obserwujemy obecnie jego intensywny rozwój i wyraźne przeobrażenia wynikające z przemian współczesnego systemu komunikacji i roli, jaką odgrywa w nim szeroko rozumiane publikowanie. Jak zauważa Maciej Kawka, ,ten kierunek rozwoju edytorstwa przynajmniej dzisiaj ma największe szanse rozwoju zarówno w perspektywie rozwoju metod badawczych, jak akademickiego kształcenia wydawców" 53 . Dlatego też rozważania Marszałka i jego koncepcja edytorstwa wydają się warte przypomnienia, mogą też stanowić interesujący punkt odniesienia dla refleksji nad aktualnym stanem badań z tego zakresu i ich współczesną problematyką.

50 K. Głombiowski, Książka w procesie komunikacji społecznej, Wrocław 1980, s. 35.

${ }^{51}$ K. Migoń, op. cit., s. 122, 189.

52 Zob. na przykład T. Bierkowski, E. Repucho, Typografia dla humanistów, Warszawa 2018, passim; M. Kawka, Trzy edytorstwa czy jedno?, s. 66; M. Wójcik, Zagadnienia wydawnicze w nauce o książce, „Toruńskie Studia Bibliologiczne” 2012, nr 1, s. 38-39.

53 M. Kawka, Tekstologia, teoria tekstu, edytorstwo..., s. 42-43. 


\section{BIBLIOGRAFIA}

Bierkowski T., Repucho E., Typografia dla humanistów, Warszawa 2018.

Dunin J., Wstęp do edytorstwa, Łódź 2005.

Głombiowski K., Książka w procesie komunikacji społecznej, Wrocław 1980.

Górski K., Sztuka edytorska. Zarys teorii, Warszawa 1956.

Gruchała J.S., Tekstologia (edytorstwo naukowe), [hasło w:] Encyklopedia ksiązki, pod red. A. Żbikowskiej-Migoń, M. Skalskiej-Zlat, t. 1, Wrocław 2017.

Gruchała J.S., Uwagi o akademickim ksztatceniu edytorów, „Konspekt” 2004, nr 19.

Hojka B., Edytorstwo, [hasło w:] Encyklopedia książki, pod red. A. Żbikowskiej-Migoń, M. Skalskiej-Zlat, t. 1, Wrocław 2017.

Jabłońska-Stefanowicz E., Wolański A., Edytorstwo. Praktyka, [hasło w:] Encyklopedia książki, pod red. A. Żbikowskiej-Migoń, M. Skalskiej-Zlat, t. 1, Wrocław 2017.

Kawka M., Tekstologia, teoria tekstu, edytorstwo..., „Konspekt” 2004, nr 19.

Kawka M., Trzy edytorstwa czy jedno? O potrzebie ksztatcenia wydawców ksiązek w Akademii Pedagogicznej, „Konspekt” 2001, nr 6.

Kocięcka M., Leon Marszatek, „Przegląd Biblioteczny” 1996, nr 4.

Kocięcka M., Marszałek Leon, [hasło w:] Słownik Pracowników Książki Polskiej, Suplement II, Warszawa 2000.

Kocięcka M., Wspomnienie o Dyrektorze Leonie Marszałku, „Biuletyn Informacyjny Biblioteki Narodowej" 1966.

Łysakowski A., Przedmiot i zadania bibliografii, [w:] Wykłady z dokumentacji naukowo-technicznej, pod red. T. Zamoyskiego, Warszawa 1951.

Marszałek L., „Editor”- forum wydawców, „Editor” 1, 1988.

Marszałek L., Edytorstwo - dyscyplina nauki o książce, „Przegląd Księgarski i Wydawniczy” 1970 , nr 23/24.

Marszałek L., Edytorstwo publikacji naukowych, Warszawa 1986.

Marszałek L., Pierwsze encyklopedie uniwersalne Państwowego Wydawnictwa Naukowego, „Editor" 3, 1990.

Marszałek L., Podstawowe wiadomości z edytorstwa i księgarstwa, Warszawa 1988.

Marszałek L., Polskie encyklopedie i słowniki bibliologiczne, „Przegląd Biblioteczny” 1985, z. 3/4.

Marszałek L., Publikacje naukowe, ,Zagadnienia Naukoznawstwa” 1984, z. 1.

Marszałek L., Warsztat edytorski Wielkiej Encyklopedii Powszechnej, „Rocznik Biblioteki Narodowej" 1966.

Marszałek L., Wydawcy wobec wyzwania czasu, „Editor” 2, 1989.

Marszałek L., Zagadnienia wydawnicze w nauce o książe, [w:] Metodologia bibliotekoznawstwa i nauki o informacji naukowej. Materiaty z sesji naukowej zorganizowanej przez Instytut Bibliotekoznawstwa i Informacji Naukowej oraz Bibliotekę Główna UAM (17-18 XII 1974 R.), Poznań 1976.

Migoń K., Nauka o książe. Zarys problematyki, Wrocław 1984.

Strzyżewski M., Współczesne edytorstwo to złożona całość, „Wielogłos. Pismo Wydziału Polonistyki UJ" 2012, nr 3.

Szymański J., Nauki pomocnicze historii, Warszawa 1983.

Talar G., Edytorstwo a nauka o ksiażce, „Studia o Książce” 5, 1975.

Trzynadlowski J., Autor, dzieło, wydawca, Wrocław 1988.

Trzynadlowski J., Edytorstwo i zagadnienia wydawnicze. Stan i perspektywy badawcze, „Studia o Książce" 12, 1982. 
Wójcik M., Zagadnienia wydawnicze w nauce o książce, „Toruńskie Studia Bibliologiczne” 2012, nr 1. Zasady typowego opracowania edytorskiego, oprac. zespół pod kier. L. Marszałka, Warszawa 1962. Zawisza J.W., [rec.] L. Marszałek, Edytorstwo publikacji naukowych. Zarys problematyki, „Roczniki Biblioteczne" 20, 1976.

BOŻENA HOJKA

\title{
THE CONCEPT OF EDITING AS A BIBLIOLOGICAL DISCIPLINE IN THE WRITINGS OF LEON MARSZAŁEK (1912-1996)
}

\begin{abstract}
Summary
Editorial topics have almost always been included in the field of book studies, but for a long time they were not subjects of systematic research. It was only in the second half of the 20th century, with a rapid development of the publishing market, that interest in editing grew considerably, leading to the emergence within bibliology of a set of questions called today bibliological editing (as opposed to scholarly-historical and philological editing). A need to develop editing understood in this manner was noted by Leon Marszałek (1912-1996), an outstanding Polish publisher, editorin-chief of encyclopaedias and dictionaries at the Państwowe Wydawnictwo Naukowe press, author of scholarly and expert publications in which he consistently popularised the idea of editing as a separate discipline practised as part of book studies, called for comprehensive research to be carried out in this area and attempted to formulate its curriculum. The article is an attempt to reconstruct the editorial concept presented in Marszałek's most important theoretical works. The author discusses his views on the subject matter in question and the scope of editorial research, its aim, methodological basis as well as interdisciplinary links. It is worth recalling those views as an interesting point of reference for the reflection on the current state of bibliological editing and its status in contemporary books studies.
\end{abstract}

KEY WORDS: Leon Marszałek (1912-1996), editing, publishing, bibliology 